\title{
Penggemar Nike Ardilla, antara Fanatisme dan Eksistensi Diri
}

\author{
Nike Ardilla Fans, between Fanaticism and Self-Existence
}

\author{
Riana Qurniati', Ratna Permata Sari² \\ 1,2 Program Studi Ilmu Komunikasi, Universitas Islam Indonesia, Sleman \\ Yogyakarta, Indonesia
}

\begin{abstract}
Author's email:
${ }^{1} 16321086 @$ alumni.uii.ac.id

${ }^{2}$ ratna.permatasari@uii.ac.id
\end{abstract}

\begin{abstract}
Nike Ardilla is a phenomenon. Even though she has passed away, the popularity of this female singer seems to have not faded since the 90s. This study examines how the fanaticism of Nike Ardilla fans at the Nike Ardilla Fans Club (NAFC) Jogja Central Java, and how the self-existence of Nike Ardilla fans in Jogja Central Java, is described. This study uses a qualitative descriptive method. Researchers collected data by conducting participant observations and interviews with six informants who have joined the NAFC Jogja Central Java with the snowball technique. The results showed that the fanaticism of Nike Ardilla fans made them unable to separate reality from fantasy. As for the description of self-existence, adult fans are more obsessed and have a higher self-existence compared to young fans, both in the online and offline world.
\end{abstract}

Keywords: Fans, Fandom, Fanatism, Self-Existence

Nike Ardilla adalah sebuah fenomena. Walau telah tiada, kepopuleran penyanyi wanita ini seakan tidak meredup sejak tahun 90-an. Penelitian ini mengkaji mengenai bagaimana perilaku Fanatisme penggemar Nike Ardilla pada Nike Ardilla Fans Club (NAFC) Jogja Jateng dan bagaimana gambaran eksistensi diri para penggemar Nike Ardilla Jogja Jateng. Penelitian ini menggunakan metode deskriptif kualitatif. Peneliti mengumpulkan data dengan melakukan observasi partisipan dan wawancara terhadap enam informan yang sudah tergabung dalam NAFC Jogja Jateng dengan teknik snowball. Hasil penelitian menunjukkan kefanatikan penggemar Nike Ardilla membuat diri mereka tidak bisa memisahkan realita dengan fantasi. Sedangkan untuk gambaran eksistensi diri, para fans berusia dewasa lebih terobsesi dan memiliki eksistensi diri yang lebih tinggi dibandingkan dengan fans muda baik eksistensi diri di dunia online maupun offline.

Kata kunci: Amazara, Digital, Komunikasi Pemasaran 


\section{PENDAHULUAN}

Berbeda dengan artis-artis di eranya yang sudah mulai redup, Nike Ardilla menjadi penyanyi yang sangat terkenal pada era 9oan. Umurnya yang masih remaja mampu membius para penggemarnya. Hingga saat ini, Nike Ardilla Fans Club telah berumur 24 tahun.

Kepopuleran Nike Ardilla meskipun telah meninggal di lingkungan masyarakat Indonesia tidak lain karena kesetiaan fansnya. Jika kita mendengar kata "fans", dapat disimpulkan bahwa fans akan erat berhubungan dengan fanatik atau kefanatikan. Fans adalah bagian yang paling terlihat dari khayalak teks dan praktik budaya (Storey, 2010). Para fans dapat menghidupi artis idolanya dengan membeli CD ataupun attribut yang dikeljuarkan oleh artis idolanya, nama artis akan semakin dikenal dan melambung tinggi saat artis tersebut memiliki banyak fans (Ardilla, 2019).

Fans-fans akan lebih mudah mengekspresikan sifat loyalnya kepada artis idola melalui fandom atau komunitas seperti komunitas fans-nya Nike Ardilla yang diberi nama "Nike Ardilla Fans Club" atau disingkat NAFC. Walaupun Nike Ardilla telah wafat pada 1995, tapi sampai saat ini masih terus berusaha membuat nama Nike Ardilla tidak padam.

NAFC memiliki acara tahunan yang wajib dilakukan, yakni memperingati tanggal lahirnya Nike Ardilla dan Tour Ziarah ke makam Nike Ardilla. Setiap tahunnya agenda ini selalu dilakukan. Selain itu, mini konser yang diadakan juga dimaksudkan untuk para fans bernostalgia dan berjumpa dengan fans-fans Nike Ardilla. Dalam mini konser yang diadakan, juga menjual atribut-atribut dengan fotofoto wajah pelantun lagu Bintang kehidupan. Setiap fans di era modern saat ini mengoleksi foto-foto Nike Ardilla. Karena mudahnya mengunduh dan menyimpan foto, para fans tidak perlu mengoleksi poster lagi. Namun, tidak jarang yang masih tetap memilih mengoleksi setiap poster-poster Nike Ardilla, sebagai simbol fanatiknya terhadap idolanya. Dalam penelitian ini, akan membahas tentang bagaimana NAFC Jogja mengekspresikan perilaku fanatisme terhadap Nike Ardilla dan bagaimana gambaran eksistensi diri para penggemar Nike Ardilla Jogja Jateng.

\section{KERANGKA TEORI}

Seorang penggemar memiliki kefanatikan yang berbeda-beda terhadap idolanya. Fanatisme adalah antusiasme yang berlebihan dan tidak rasional untuk pengabdian kepada, suatu teori, keyakinan, atau garis tindakan yang menentukan sikap yang sangat emosional, dan kefanatikan misi serta praktik yang tidak mengenal batas-batas. (Ahmadi dalam Rafsanjani, 2014).

Fanatisme merupakan ekspresi yang berlebihan untuk menggambarkan kecintaan seseorang terhadap suatu hal atau golongan untuk mendapatkan kepuasan yang dirasakan oleh diri seseorang tersebut. Fanatik adalah suatu wujud dari sikap fanatisme yang ada pada diri seseorang agar dapat diakui, biasanya dapat berupa tindakan atau perilaku yang ditunjukkan untuk memuaskan keinginannya.

Efek perilaku fanatisme yang ditujukkan oleh para fans dapat dilihat dari cara mereka memiliki untuk menunjukkan bahwa mereka Fans dengan mengkoleksi $C D$, kaset, mengunduh foto-foto penyanyi tersebut serta menonton konser-konser penyanyi idola mereka, hingga menata dekorasi kamar penuh dengan aksesoris idolanya (Nataliawaty, 2002).

Menurut Haryatmoko (2003) ada empat faktor yang menumbuhkan fanatisme. Pertama, memperlakukan kelompok tertentu sebagai ideologi. Ideologi di dunia bermacam-macam dan 
setiap kelompok mempunyai ideologi yang berbeda-beda. Bukan hanya itu, setiap kelompok juga memiliki ciri khas masingmasing dalam berideologi, fanatisme terjadi salah satu faktornya adalah memperlakukan kelompok tertentu sebagai ideologi. Ini terjadi karena ada kelompok yang mempunyai pemahaman eksklusif dalam pemaknaan hubunganhubungan sosial.Kedua, sikap standar ganda. Kelompok organisasi yang satu dengan kelompok organisasi yang lain selalu memakai standar yang berbeda untuk kelompoknya masingmasing. Ketiga, komunitas dijadikan legitimasi etis hubungan sosial. Sikap tersebut bukan mensakralkan hubungan sosial, tetapi lebih kepada pengklaiman tatanan sosial tertentu yang mendapat dukungan dari kelompok tertentu. Keempat, klaim kepemilikan organisasi oleh kelompok tetentu. Sikap tersebut seringkali seseorang mengidentikkan kelompok sosialnya dengan organisasi tertentu yang berperan aktif dan hidup di masyarakat.

\section{METODE}

Penelitian ini merupakan penelitian kualitatif. Penelitian kualitatif sebagai penelitian yang bermaksud memahami fenomena tentang apa yang dialami oleh subjek penelitian misalnya perilaku, persepsi, motivasi, tindakan dan lain-lain secara holistik dan dengan cara deskripsi dalam bentuk kata-kata dan bahasa, pada suatu konteks khusus alamiah dan dengan memanfaatkan berbagai metode alamiah (Sari, 2012).

Objek penelitian ini adalah para fans yang sudah tergabung dalam komunitas NAFC Jogja Jateng. Dalam satu sosial media WhatsApp terdapat 78 anggota NAFC. Di sini, peneliti melakukan wawancara terhadap enam informan. Kemudian, untuk pemilihan narasumbernya, peneliti menggunakan teknik snow ball.
Pengumpulan data menyangkut informasi yang berhubungan dengan Nike Ardilla dan rekaman serta dokumentasi saat proses wawancara dengan informan dan kemudian dilakukan pengamatan lagi. Sebelumnya, peneliti telah melakukan observasi terlebih dahulu pada penggemar Nike Ardilla yang tergabung dalam NAFC Jogja Jateng.

Data dianalisis berdasarkan tematema untuk kemudian disajikan dalam suatu narasi berdasarkan tema. Setelah itu, ditarik kesimpulan.

\section{HASIL DAN PEMBAHASAN Kelompok Penggemar Nike Ardilla Fans Club (NAFC) Jogja Jateng}

NAFC Jogja Jateng merupakan sebuah komunitas yang diawali atas kesamaan dalam mengidolakan Nike Ardilla. Kesamaan ini mempertemukan mereka dalam sebuah komunitas penggemar Nike Ardilla.

Komunitas ini tercipta karena kesamaan idola yang mereka idolakan yaitu Nike Ardilla. Dalam dunia Musik Nike Ardilla dikenal sebagai lady rock yang tidak akan dilupakan. Prestasi yang diperoleh dan berbagai karya-karyanya hingga saat ini masih sering ditemukan seperti lagu-lagu Nike yang banyak diputar ditempat-tempat umum.

Dengan lagu-lagu yang memiliki makna dan selalu sampai pesannya kepada pendengar, membuat banyak pendengar Nike yang ikut dalam makna lagu yang didengarkan. Berawal dari seringnya mendengarkan lagu, membuat penggemar Nike bergabung dalam komunitas yang terbentuk dari tahun 2017 dan diketuai oleh Dion.

Hingga saat ini, anggota dari Nike Ardilla Fanc Club Jogja mencapai 78 orang, yang terdiri dari penggemar usia 16 tahun hingga berumur lebih dari 40 tahun. Mereka memiliki kesamaan dalam selera dan alasan mengidolakan Nike Ardilla. Hal ini menunjukkan mereka sedang menjalani 
sebuah kultur yang sama atau berada dalam satu lingkup budaya yang sama.

Penyebaran atau kebutuhan komunikasi dari komunitas ini mencapai lingkup nasional dikarenakan setiap komunitas Nike Ardilla selalu dibawahi oleh NAFC pusat yang terus memantau komunitas penggemar Nike di daerahdaerah. Selain itu, jika ada acara atau kegiatan NAFC pusat selalu berkoordinasi dan setiap komunitas selalu sering berhubungan dengan sesama anggota komunitas didaerah lain.

Media yang digunakan dalam komunikasi ini adalah WhatsApp, pengguaan aplikasi WA membuat setiap angota akan lebih mudah dalam berkomunikasi, serta grup WA yang dibuat khusus untuk para penggemar Nike Ardilla memudahkan setiap anggota dalam memberikan informasi ataupun sekedar menanyakan kabar dari anggota lain.

Media lain yang digunakan adalah Instagram, NAFC memiliki akun instagram dengan platform mengedepankan visual baik foto maupun video. Instagram ini sendiri dijadikan sarana penyebaran informasi oleh Nike Ardilla Fans Club.

\section{Fanatisme Penggemar Nike Ardilla}

Atas dasar kesamaan sudut padang dalam mencintai dan mengidolakan Nike Ardilla, penggemar Nike Ardilla menganut paham fanatik (fanatisme) karena fanatisme penyebab terjadinya fanatik. Paham tersebut pada akhirnya menciptakan sebuah komunitas pecinta Nike Ardilla yang diberi nama NAFC Jogja Jateng. Komunitas NAFC kemudian dijadikan legitimasi etis hubungan sosial. Hal ini termasuk dalam faktor tumbuhnya fanatisme dalam diri penggemar yang dikemukakan oleh Haryatmoko (2003).

Uraian berikut, akan memaparkan bentuk-bentuk fanatisme penggemar Nike
Ardila. Uraian akan didasarkan pada teori Jenkins (Sari, 2012).

\section{Membeli Apapun yang berhubungan dengan Idola}

Seorang penggemar akan dikatakan mencapai tahap menjadi penggemar yang fanatik jika penggemar tersebut rela membeli apapun yang berhubungan dengan idolanya. Menurut Jenkins, apapun yang berhubungan dengan idolanya akan rela dibeli oleh seorang penggemar. Jika idola tersebut sudah meninggal, maka penggemar akan membeli dan menyimpan semua benda yang berhubungan dengan idola tersebut untuk membuat idolanya tetap dikenang.

Penjualan merchandise Nike Ardilla menembus angka tinggi. Nike Ardilla telah meninggal, tapi memiliki museum Nike Ardilla yang dikelola oleh keluarga dari Nike yang rutin membuat merchandise Nike yang dibeli oleh penggemar baik online maupun bias dating langsung ke Museum Nike Ardilla. Beberapa kali, keluarga dan tim manajemen NAFC Pusat membuat acara yang di dalamnya penggemar dapat membeli merchandisemerchandise yang telah di jual oleh keluarga.

Ditemukan di sebuah aplikasi jual beli online Tokopedia, sebuah akun menjual majalah terbitan 1990 edisi Nike Ardilla dan telah terjual habis dengan harga 5 juta rupiah. Informan bernama Nining rela menyisihkan uangnya untuk membeli setiap merchandise keluaran terbaru yang dibuat oleh keluarga Nike Ardilla. Setiap ada produk baru, Nining akan selalu diberitahukan terlebih dahulu karena Nining salah satu penggemar Nike yang paling fanatik.

Pembelian merchandise ini didasari keinginan informan untuk memiliki apapun yang berhubungan dengan Nike Ardilla. Ini karena informan memiliki kepuasan tersendiri jika dirinya memiliki 
banyak koleksi barang tetang Nike dan dikenal banyak orang dengan banyaknya koleksi Nike yang dirinya miliki.

\section{Devote Their Lives To The Cultivation Of Worthless Knowledge}

Fanatisme dapat menjadikan penggemar kehilangan banyak waktu, karena penggemar yang fanatik kepada idolanya akan menghabiskan hidup mereka untuk mengolah pengetahuan yang sangat kurang bermakna. Pengetahuan yang dimaksud adalah pengetahuan atau informasi seputar idolanya. Mereka berusaha melambungkan nama idolanya agar tetap eksis dan dikenal oleh banyak orang.

Pada dasarnya, seorang penggemar akan selalu menjadi sosok utama agar sang artis idola tetap memiliki nama besar dan dikenal oleh banyak orang. Jika seorang mengidolakan seorang artis atau penyanyi maka penggemar tersebut akan mencari tau apapun atau kehidupan dari idolanya tersebut.

Sebagai penyanyi lawas era 90an, yang telah meninggal orang akan sulit untuk mengenali dan menghafal kepribadian atau hal yang berkaitan dengan Nike, dari mulai album, lagu hingga film-film yang pernah dibintangi oleh Nike Ardilla. Namun, ini tidak berlaku bagi para penggemar Nike Ardilla.

Para penggemar Nike Ardilla dengan cepat dan lugas menerangkan sosok dan kepribadian dari Nike Ardilla, hafal semua judul lagu dan film-film Nike Ardilla hingga kisah cinta Nike Ardilla. Para penggemar juga akan menjelaskan secara rinci jalan cerita film-film yang pernah dibintangi oleh Nike Ardilla.

Setiap lagu-lagu Nike akan ditemukan makna dan memiliki arti tersendiri oleh para penggemar Nike Ardilla. Juhaeriah, misalnya, mengaku memiliki kisah atau cerita tersendiri dengan beberapa lagu Nike dalam perjalanan hidupnya menemukan seorang suami. Ia mengaku selalu mendengarkan lagu-lagu Nike saat pertama bertemu dengan suami hingga menikah.

Para penggemar juga dengan sengaja menghafal lirik lagu, menonton film, mengadakan event, mencari lagu-lagu Nike di YouTube serta membuat videovideo dengan backsound lagu-lagu Nike dan kemudian di unggah di akun media social milik mereka. Kegiatan ini membuat durasi akses media informan melebihi durasi pengguna media pada umumnya.

Dalam situs yang diikuti di situs jejaring sosial, informan ikut aktif bergabung dalam fan page dan melakukan aktivitas penggemar dengan mengikuti fan gathering, fan project, konsumsi dan lainlain.

Place Inappropriate Importance On Devalued Cultural Material

Biasanya, seorang penggemar akan menempatkan idola ditempat yang istimewa dalam kehidupannya. Saat orang normal lainnya menganggap bahwa idola mereka biasa saja selayaknya orang biasa maka penggemar yang fanatik akan bertolak belakang pada pernyataan tersebut.

Tipikal ini bisa digambarkan dengan ungkapan "Nike Ardilla hanyalah seorang penyanyi”. Namun bagi NAFC, Nike Ardilla sudah menjadi bagian dari hidup mereka. Mereka rela mendedikasikan waktu, pikiran, dan perasaan untuk menyukai Nike Ardilla. Informan Nining, misalnya, akan merasa sedih dan kecewa jika nama Nike akan terlupakan dan dilupakan begitu saja. Terlebih, jika tanggal meninggal dan tanggal ulang tahun dari Nike Ardilla tidak ada pemberitaan di televisi.

Are Feminized And Desexualized Through Their Intimate Engagement With Mass Culture

Dengan menyukai objek tertentu, mereka disatukan dengan satu nama, tidak perduli laki-laki ataupun perempuan. 
Menurut Jenson, orang-orang akan mendapati penggemar sebagai orangorang yang aneh dalam kaitannya dengan obsesi mereka terhadap objek kesukaan mereka.

Hal inilah yang terjadi kepada para informan. Ikatan yang dimiliki dengan budaya penggemar Nike Ardilla membuat mereka merasa terisolasi dengan orangorang yang tidak memahami arti dari "penggemar". Oleh karena itu, wajar saja keenam informan mengaku lebih nyaman berkumpul dengan sesame penggemar Nike Ardilla karena objek kesukaan yang sama dan obrolan yang sejalan.

Menanggapi tanggapan-tanggapan negatif lingkungan, keenam informan mengatakan bahwa mereka tidak menyukai orang-orang yang meremehkan mereka karena mengidolakan artis yang sudah meninggal. Baginya, Nike Ardilla adalah sosok motivator, orang yang memiliki jiwa sosial yang tinggi yang patut untuk dicontoh dan lebih termotivasi untuk melakukan hal baik. Dengan menjadi penggemar, ia menghargai usaha idola untuk mencapai kesuksesan.

\section{Are Unable To Separate Fantasy From Reality}

Hal ini erat kaitannya dengan proses pemaknaan yang dilakukan penggemar. Jika sudah fanatik, banyak penggemar sulit memisahkan realita dengan fantasi. Menurut penuturan informan Nining, berada di kamar khusus koleksi bendabenda Nike Ardilla memiliki ketenangan tersendiri

Setiap dirinya sedang tidak enak badan ataupun sedang memiliki masalah dalam kehidupan akan lebih tenang jika mendengarkan lagu-lagu Nike didalam kamar tersebut. Saat sudah berada dalam kamar tersebut, dunianya sudah beda, dunia yang terjadi ialah dunia khayalan yang bias membuat Nining lebih tenang.
Selanjutnya, Nining menuturkan jika dirinya beberapa kali melihat Nike Ardilla menghampiri dirinya di kamar tersebut. Hal ini yang membuat Nining merasa dirinya akan lebih tenang dan damai jika berada di kamar tersebut dengan mendengarkan lagu-lagu dan melihat fotofoto Nike.

Tipe penggemar di atas, secara garis besar menunjukkan bahwa fanatisme terhadap Nike Ardilla yang mempengaruhi informan secara internal dan eksternal. Fanatisme memengaruhi diri informan secara internal sehubungan dengan ketidak tepatan penggunaan emosi dan rasionalitas. Pernyataan ini ini sesuai dengan pendapat Jenkins bahwa penggemar digambarkan telah menghabiskan waktu hidupnya dengan pengetahuan yang tidak penting dan tidak mampu menyinergikan diri dengan realitas. Fanatisme berpengaruh dengan eksternal terkait hubungan informan dengan lingkungan sekitar. Dalam hal ini, Jenkins menggambarkan penggemar dengan ketidak mampuan menyesuaikan diri dengan lingkungan (socially maladjusted).

Data penelitian menunjukkan bahwa salah satu alasan informan tetap setia menjadi penggemar Nike Ardilla adalah adanya dorongan faktor internal yang berasal dari dalam diri informan sehubungan dengan rasa senang dan puas yang didapatkan ketika menjadi penggemar Nike Ardilla.

Dari sini, diketahui bahwa motif informan melakukan aktivitas penggemar adalah untuk memenuhi kebutuhan afeksi dan emosi didalam dirinya.

\section{Eksistensi Diri}

Istilah eksistensi berasal dari kata 'eks' atau keluar dan 'sistensi' yang diturunkan dari kata kerja 'sisto' yang berarti 'berdiri' atau 'menempatkan.' Jadi, eksistensi dapat diartikan sebagai manusia berdiri sebagai 
diri sendiri dengan keluar dari dirinya, manusia menjadi sadar bahwa dirinya ada (Artanti et al., 2020; Dewi \& Hadiwijaya, 2016).

Untuk menunjukkan bahwa diri mereka ialah penggemar Nike Ardilla, pengambilan setiap tindakan dalam menunjukkan identitas diri sebagai penggemar menjadi syarat mereka untuk mewujudkan eksistensi yang ingin mereka tunjukkan. Eksistensi yang ingin ditunjukkan secara sederhana dibangun melalui media, dimana media ini mewakili diri mereka dalam berekspresi menjadi penggemar Nike Ardilla.

Mengunggah foto melalui media merupakan salah satu cara mereka dalam menunjukkan eksistensi dirinya, hal ini menunjukkan adanya kebebasan. Kebebasan dalam menemukan arti merupakan sesuai yang sangat penting dalam menemukan eksistensi diri. Kebebasan ini mengandung arti bahwa setiap individu tidak diatur oleh faktorfaktor non spiritual atau kondisi-kondisi dari lingkungan. Individu memiliki kebebasan untuk memilih bagaimana akan bertingkah laku jika ingin menjadi sehat secara psikologis. Dengan demikian, individu yang tidak memiliki kebebasan akan menjadi neurotis dan hal tersebut akan menghambat penemuan potensi- potensi diri yang pada akhirnya mengganggu pencapaian eksistensi diri.

John Storey dalam Cultural Studies dan Kajian Budaya Pop menyebutkan bahwa penggemar selalu dicirikan sebagai suatu kefanatikan yang potensial dimana bisa dilihat dari perilaku yang berlebihan (Sari, (2012), hal. 138)

Hal tersebut terlihat pada dua fans Nike Ardilla, yaitu Juhaeriah dan Nining yang memerlihatkan kefanatikan pada idola mereka dengan menggunakan bagian nama dari Nike Ardilla, mengkoleksi banyak barang-barang hingga membuatkan kamar sendiri untuk barangbarang tersebut, serta mengunggah foto, video.

Eksistensi Diri Penggemar Nike Ardilla Secara Online

Juhaeriah mengunggah foto-foto kebersamaannya bersama NAFC Jogja Jateng pada acara peringatan tanggal dibentuknya NAFC Jogja Jateng. Setiap pertemuannya dengan sesama penggemar Nike Ardilla Juhaeriah selalu mengunggahnya di akun media sosialnya Facebook. 


\section{Gambar 1. Unggahan pada Akun Facebook Juhaeriah}

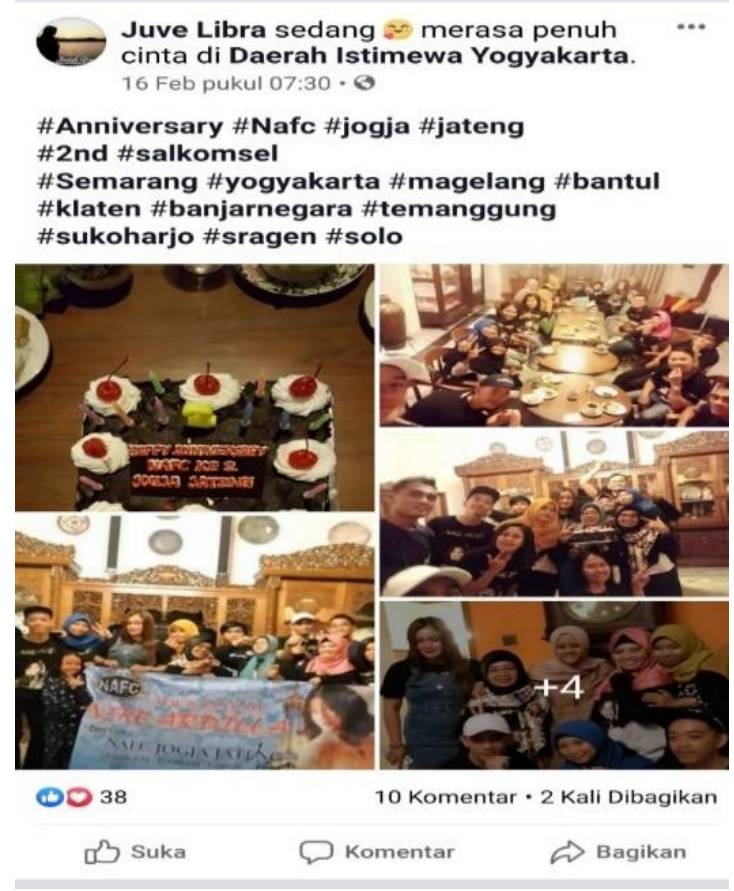

Sumber: Akun Facebook Juhaeriah (Juve Libra)

Selain Facebook, Ia juga sering kali mengunggah di akun instagram pribadinya. Foto-foto Nike Ardila dan foto aktivitasnya di fandom Nike Ardila juga sering kali diunggah dihalaman pribadi akun instagramnya.

Pada profil instagram juhaeriah dalam akun (@Juvelibra), terlihat cukup sering mengunggah beberapa foto dan video tentang Nike Ardilla. Beberapa kali Juhaeriah mengunggah setiap gabungan foto dan tulisan hari jadi dari fandom Nike Ardilla, dan video-video yang ia buat dengan lagu-lagu Nike Ardilla.

Paul Wills (Sari, 2012) mengatakan bahwa dalam kehidupan penggemar budaya pop, para individu dan kelompok itu berusaha secara kreatif membuktikan kehadiran, identitas dan makna dari ungkapan perasaan, tanda dan simbol dalam kehidupan mereka, melalui suatu upaya yang disebut kreativitas simbolik.

Sebagai seorang fans Nike Ardilla Juhaeriah dan teman-temannya membuktikan eksistensi diri mereka menjadi seorang penggemar Nike dengan mengunggah foto dan video tentang Nike Ardilla, menggunakan foto profil Nike dalam akun media sosialnya, menggunakan nama Nike di akun media sosialnya serta mengkoleksi barangbarang tentang Nike. 

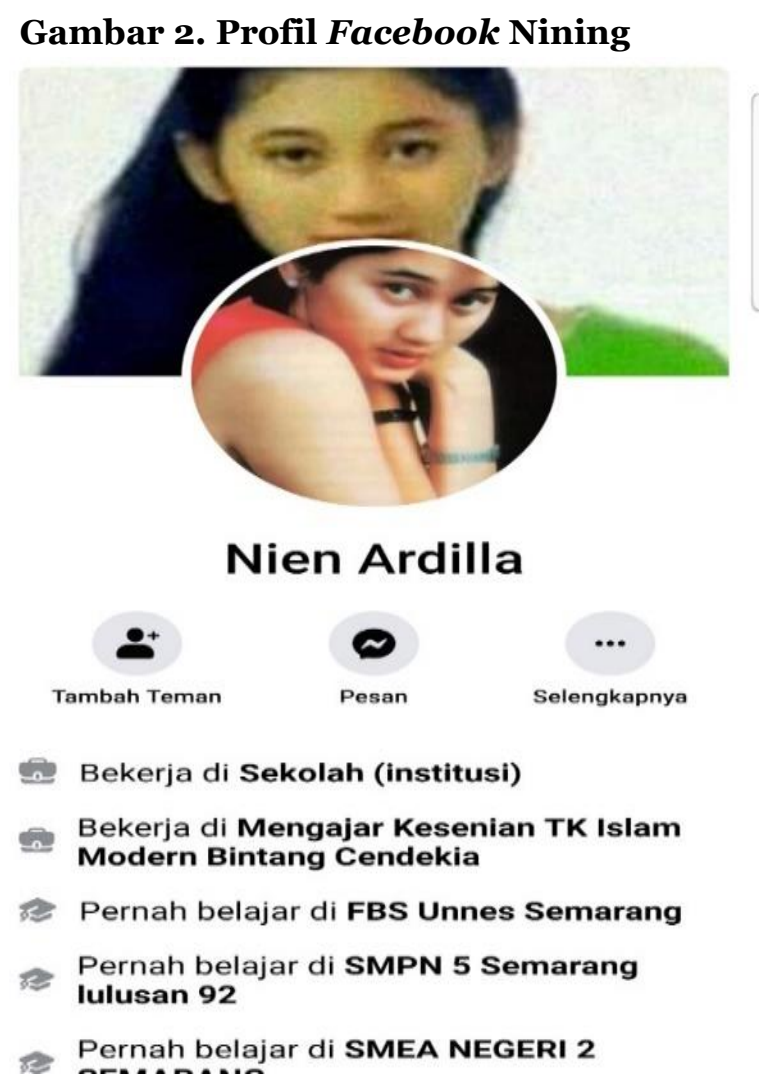

Sumber: Akun Facebook Nining (Nining Ardilla)

Nining menggunakan nama ardilla nama yang diambil dari Nike untuk digunakan dalam menamai akun media sosial Facebook miliknya. Tidak hanya nama Nike Ardilla yang digunakan pada akun miliknya, tetapi foto-foto Nike dijadikan foto profil dan foto sampul di akun Facebook-nya tersebut. Selain itu, Nining sangat sering mengunggah fotofoto dirinya di kegiatan-kegiatan tentang Nike yang ia ikuti dan pertemuanpertamuan dengan sesama penggemar Nike Ardilla. Nining adalah salah satu penggemar yang paling sering mengikuti acara-acara tentang Nike dan memiliki banyak sekali barang-barang atau foto Nike Ardiila.
Eksistensi Diri Penggemar Secara Offline

Para penggemar dengan kefanatikannya memiliki rasa untuk mengkoleksi barang atau benda-benda tentang idolanya untuk menunjukkan eksistensi dirinya kepada orang lain. Tidak jarang, penggemar akan menyimpan dengan baik semua koleksi-koleksi atau barang yang berhubungan dengan idolanya dikamar ataupun di rumahnya.

Peneliti tertarik dengan menanyakan apa saja barang atau merchandise tentang Nike yang informan miliki dan disimpat atau diletakkan pada kamar ataupun rumah informan.

Jawaban disampaikan oleh Nining adalah barang atau benda tentang Nike sejak 1989. Nining mengatakan memiliki kamar sendiri untuk menyimpan semua koleksi barang dan merchandise dari Nike Ardilla. 


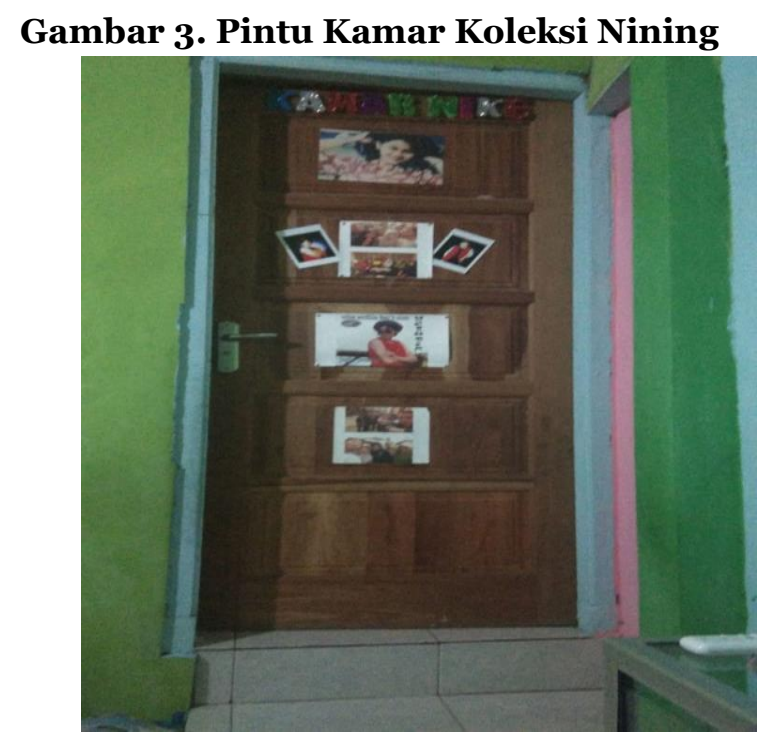

Sumber: Dokumen Pribadi Peneliti

Gambar diatas ialah tampak dari pintu kamar milik Nining yang disiapkan untuk menyimpak koleksi barang dan merchandise tentang Nike. kamar tersebut diberi nama "kamar nike". Di kamar inilah, koleksi Nining disimpan.
Nining memiliki berbagai koleksi barang yang disimpannya dari tahun 1989. Diatara barang koleksi tersebut ialah kaos, gelas, topi, CD atau kaset, poster dan lain sebagainya.

\section{Gambar 4. Koleksi Poster Dan Merchandise Nike Ardilla}

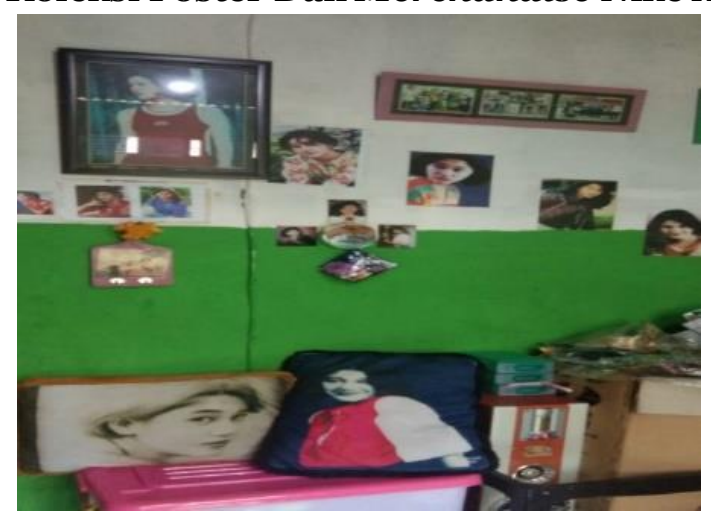

Sumber: Dokumen Pribadi Peneliti

Pada gambar di atas, tampak isi "kamar nike" milik Nining. Tampak foto serta foto dan juga bantal dengan wajah Nike terlihat pada kamar tersebut. Beberapa perilaku yang setiap malam dilakukan adalah mendengarkan lagu-lagu Nike di kamar tersebut. Nining mengatakan pada peneliti bahwa setiap ia merasa lelah atau memiliki masalah dikehidupannya ia akan mendengarkan lagu-lagu Nike dan beranggapan setelah mendengarkan lagunya dirinya menjadi lebih tenang dan tidak merasa lelah. Bagi nining, memiliki kepuasan tersendiri jika mengikuti acara dan mengkoleksi barang tentang Nike. Pernyataan tersebut disampaikan oleh Nining kepada peneliti.

Nining mengaku tidak mengidolakan figure lain selain Nike Ardilla. Sejak awal kemunculan Nike Ardilla hingga saat ini, Nining tidak mengidolakan figure lain selain Nike Ardilla. 
Berbeda dengan Nining, Ayu salah satu fans yang masih sekolah mengaku tidak pernah berusaha untuk mengikuti gaya dari Nike. Ayu mengaku mengidolakan Nike hanya sewajarnya saja karena tidak boleh mengidolakan manusia secara berlebihan. Mendengar pernyataan tersebut, peneliti tertarik untuk menanyakan alasan mengapa Ayu bergabung di fandom Nike Ardilla dan mengikuti acara-acaranya.

Peneliti menarik kesimpulan bahwa penggemar Nike Ardilla yang berusia di atas 23 tahun seperti Nining dan Juhaeriah lebih memiliki banyak merchandise dan juga kefanatikannya lebih terlihat. Nining dan Juhaeriah tidak mengidolakan siapapun kecuali Nike Ardilla. Bagi Nining dan Juhaeriah, Nike Ardilla adalah sumber inspirasi yang tidak akan pernah mati dan tidak akan tergantikan.

Kecintaannya dan keobsesiannya kepada Nike Ardilla tampak jelas pada pernyataannya yang disampaikan kepada peneliti. Ayu, Wulan dan Inung informan yang berusia di bawah 23 tahun mengidolakan Nike hanya sewajarnya dan kefanatikan tersebut tidak tampak besar ada dalam diri mereka. Ini karena mungkin mereka tidak mengalami secara langsung ketika Nike Ardilla pada puncak kepopulerannya. Akibatnya, kekaguman mereka tidak sekuat para pendahulunya.

Koleksi barang dan merchandise yang dimiliki oleh penggemar berusia di bawah 23 tahun juga tidak banyak yang cenderung memikirkan uang untuk membeli barang tersebut dan juga usaha untuk mendapatkan barang-barang tersebut tidak begitu kuat.

\section{KESIMPULAN}

Penelitian ini menunjukkan bahwa penggemar Nike Ardilla memiliki beberapa cara untuk menunjukkan eksistensi diri sebagai penggemar Nike Ardilla. Setelah melakukan penelitian dan analisis, peneliti dapat menyimpulkan bahwa, dalam rumusan masalah pertama, bagaimana perilaku fanatisme penggemar Nike Ardilla pada NAFC Jogja Jateng, fans Nike Ardilla yang fanatik menimbulkan perilaku fanatisme yang mempengaruhi diri mereka secara internal sehubungan dengan ketidak tepatan memisahkan realita dengan fantasi.

Fans akan merasakan kehadiran Nike Ardilla didekatnya setiap saat dirinya mendengarkan lagu-lagu Nike Ardilla dengan suasana kamar yang tenang dan hening, mereka akan merasakan Nike Ardilla berada di dalam kamarnya saat itu dan seketika suasana hati menjadi lebih tenang. Hal tersebut menunjukkan fanatik terhadap Nike Ardilla dengan konsep Are Unable To Separate Fantasy From Reality memiliki kesamaan dimana personalisasi perilaku fanatik dalam mengidolakan Nike Ardilla sulit untuk memisahkan realita dengan fantasi.

Gambaran eksistensi diri yang ditunjukkan oleh penggemar Nike Ardilla Jogja Jateng, pada penelitian ini peneliti membagi informan menjadi dua, yaitu fans yang memiliki usia diatas 23 tahun (dewasa) dan fans yang memiliki usia dibawah 23 tahun (muda).

Fans dewasa memiliki tingkat eksistensi diri yang lebih besar terlihat dari eksistensi diri yang ditunjukkan secara online dan offline. Mereka cenderung banyak mengkoleksi benda dan merchandise Nike Ardilla serta sangat terobsesi dengan Nike Ardilla, dengan tidak mengidolakan figure lain selain Nike Ardilla. Selain itu, fans dewasa menujukkan eksistensi diri secara online di media sosial seperti Instagram, Facebook dan WhatsApp. Untuk fans muda, memiliki eksistensi diri yang tidak besar, mereka tidak banyak mengoleksi benda-benda maupun merchandise Nike dan jarang menunjukkan eksistensi diri secara online di media sosialnya. 


\section{DAFTAR PUSTAKA}

Ardilla, N. (2019). "Biografi Nike Ardilla." https://www.kenangan.com/biografi /nike-ardilla

Artanti, Y., Sofyanti, D., Reza, M. D., \& Hartanti, W. (2020). Eksistensi diri tiga perempuan dalam trois femmes puissantes karya Marie Ndiaye. LITERA, 19(3), 487-504. https://doi.org/10.21831/ltr.v19i3.36 011

Dewi, M., \& Hadiwijaya, M. (2016). Perencanaan Komunikasi Pemerintah Kota Palembang dalam Kampanye Program Palembang EMAS (Elok, Madani, Aman, Sejahtera). Jurnal Komunikasi, $10(2)$.

https://journal.uii.ac.id/jurnalkomunikasi/article/view/7599/6633

Haryatmoko. (2003). Mencari akar fanatisme ideologi, agama, atau pemikiran. In Ghalia Indonesia.
Nataliawaty, R. D. (2002). Penggemar setia Sheila On 7 (Studi tentang fanatisme dan pengidolaan public figure). In Universitas Gadjah Mada. Universitas Gadjah Mada.

Rafsanjani, A. (2014). Analisis fanatisme perilaku penggemar boyband korea [universitas negeri yogyakarta]. In Universitas Negeri Yogyakarta. https://eprints.uny.ac.id/21510/4/4. BAB II.pdf

Sari, R. P. (2012). Fandom dan konsumsi media: Studi etnografi kelompok penggemar super junior, ELF Jogja. Jurnal Komunikasi, 6(2), 79-90.

Storey, J. (2010). Cultural studies dan kajian budaya pop. In Jalasutra. 